the 'twenties. But coming as a postgraduate to University College, London, he fell under the spell of Petrie and imbibed something of his flair for the humanist value of material objects made by man. This combination found original expression in the "Studies" and developed. ever more fruitfully in his maturer works : for these remained works of scholarship and interpretation.

Of course, Frankfort was no armchair archæologist-he could never have been a great interpreter had he been that. He gained field experience and added to human knowledge first in directing the Egypt Exploration Society's excavations at Tell el-Amarna and then as field director of the Iraq Expedition of the Oriental Institute of the University of Chicago. The latter post gave not only opportunities of studying the monuments in their proper setting but also of organizing a scientific expedition on a lavish scale. The scientific value of the results obtained at Tell Asmer and Khafaje are essentially the fruits of Frankfort's success as its organizer. For though the expedition did uncover some spectacular objects-hoards of early Sumerian statues, for example-it was the (in Mesopotamia) unprecedented thoroughness and accuracy of the planning, recording and conserving of all finds that have invested the latter with unique historical significance. The publication, still far from complete, had been planned by Frankfort, and his own personal contributions-two volumes devoted to the Sumerian statuary-disclose his sensibility as an art critic and vigour in interpretation.

Still, it is in more comprehensive syntheses, written while he was professor in Chicago and later director of the Warburg Institute in the University of London, that Frankfort's genius found fullest expression. In "Kingship and the Gods", and perhaps still more in the introduction and conclusion (written in collaboration with his first wife) to "An Essay on Speculative Thought in the Ancient Near East", entitled in Great Britain "Before Philosophy" and in the United States. "The Intellectual Adventure of Ancient Man", the reader can see how successfully and naturally an archrologist can assume the role of philosopher and sociologist.

V. G. Childe

\section{Dr. Henri Mineur}

Wrire the untimely death of Henri Mineur, which occurred after a short illness in Paris on May 7 , France has lost one of her most distinguished astronomers, and the Paris Observatory one of the best-known members of its staff.

Henri Mineur was born at Lille in 1899. Entering the army at the age of eighteen, he served for a few months with the Engineers and was demobilized with the rank of second lieutenant. Completing his interrupted education at the École Polytechnique, he graduated in 1921 and took his doctorate in mathematical sciences in 1924. At this stage he decided to make his career in astronomy and accepted a post as assistant astronomer at the Paris Observatory in 1925. Within eleven years of work at the Observatory, he had made such a name for himself that he was appointed, at the age of thirty-seven, as the first director of the newly established Institut d'Astrophysique. Work at the Institute had not got into full swing when, at the outbreak of the Second World War, it was virtually suspended, and he became director of a mathematical laboratory devoted to tho solution of defence problems. Enlisting in the Armed Forces in 1940, he was appointed professor at the school of military engineering at Versailles shortly before the fall of France. Demobilized in August 1940, he joined the resistance movement and was dismissed from his official posts by the Vichy Government in 1941. Three years later he was reinstated by the new French Government and served for a short while as captain in an anti-tank unit. Again demobilized in 1946, he turned his energies once more to astronomy, and by the date of his death had re-established the Institut d'Astrophysique as a national postgraduate centre for theoretical and observational attacks on current problems on the frontiers of astrophysics.

Mineur's personal researches covered a wide field in celestial mechanics, pure mathematics, relativity theory and statistics as well as in astronomy. $\mathrm{He}$ will perhaps be best remembered for his work on differential galactic rotation, carried out independ. ently of Oort's, but leading by somewhat different methods to substantially the same conclusions, namely, that the Galaxy is rotating about a centre some 8,000 parsees distant towards galactic longitude $325^{\circ}$, at a rate giving one complete turn in 250 million years in the solar neighbourhood. To his credit are also a number of allied investigations into the equilibrium of open galactic clusters, the timescale of the universe, and absorption of light in interstellar space. His early training as an observer in the Paris Observatory, and, later, his everyday contact with practising astronomers working in the Institut d'Astrophysique under his general direction, combined to confer on his theoretical work a practical insight which lent increased authority to his results.

M. Mineur was awarded the Damoiseau Prize of the Paris Academy of Sciences in 1944 and the Montyon Prize in 1950. He was created Chevalier of the Légion d'Honneur in 1949 . A. HunTer

\section{Dr. Loyd A. Jones}

Dr. LOYD A. Jones, who died unexpectedly on May 15 at his home in Rochester, New York, a fortnight after his retirement, was well known for his scientific work in photography. He was born in Nebraska in 1884 and, after graduating in the University of Nebraska, was for two years assistant in the Physics Department of that University, assistant physicist at the U.S. National Bureau of Standards for another two years and then joined the Research Laboratories, Eastman Kodak Company, when they were formed in 1912. He soon became chief physicist and head of the Physics Division.

From then onwards Jones's interests were almost exclusively his work on photography and on seientific committees, and his home and garden. He graduated as an electrical engineer, and something of the qualities of an engineer are to be found in much of his published work. This amounts to about eighty papers. His early work was mainly concerned with the measurement of the properties of photographic materials, the provision of instruments for doing so, and related subjects. The major interest was in sensitometry-the measurement of speed and contrast-and tone-reproduction. The culmination of this work was the paper of 1939, "The Evaluation of Negative Film Speeds in Terms of Print Quality", wherein the criterion of correct exposure of the negative was whether the negative gave as good a 
print as could be obtained from that negative material whatever the exposure. The quality of the prints was estimated by purely visual judgment, without reference to any physical measurements. The process sounds, and indeed was, laborious; but something of the kind is inevitable, and in Loyd A. Jones's hands it led to a physical measurement which correlated well with the observed speed. This way of measuring speed was adopted by the American Standards Association and the British Standards Institution. The same characteristic approach is to be found in his later papers, on graininess and granularity, and on sharpness, wherein the main effort is directed to the discovery of a purely physical measurement which correlates well with some visual estimate.

Loyd A. Jones served on many scientific bodies, notably on the Colorimetry Committee of the Optical Society of America and the sectional committee on photography of the American Standards Association, for many years. Besides the recognition which he received from scientific and photographic societies in the United States, the Royal Photographic Society of Great Britain awarded him its Progress Medal, the Hurter and Driffield Medal and an honorary fellowship. He leaves a wife and many friends to regret his death so soon after retirement. E. R. DAvIES

\section{Mr. Hugh Griffiths}

THE chemical engineering profession has lost a doughty fighter in Hugh Griffiths, who died on June 26, 1954. He was born at Middlesbrough on July 28, 1891, and a very strong influence on his career was his contact there with $\mathbf{A}$. F. van der Heyden, who laid the foundation of his love for mathematics. He took his A.R.C.Sc. in chemistry and was for the most part of his life in consulting practice. His command of the German language and his contacts on the Continent proved most valuable in this connexion.

In 1945 he was elected president of the Institution of Chemical Engineers. As a biography is contained in the Transactions for that year, it is now opportune to try to assess his outstanding contribution to the profession. This was undoubtedly his advocacy of the use of the 'Home Paper' as a part qualification for associate membership. He came into the chemical engineering profession as a young man with the practical heritage of the Victorian period behind him. First and foremost with him was the essential engineering background-the need for a practical estimate of the magnitude of the problem and the sizes involved. It was his mathematical and scientific training which then enabled him to apply fundamental conceptions to rule-of-thumb methods, and to develop processes in a manner not dreamt of by his forbears.

His philosophy in supporting the use of the 'Home Paper' for examination purposes was the realization that, if a student is faced with a problem such as, for example, the design of a plant required for the manufacture of 10 tons a day of mono-nitrotoluene, it brings out all that is latent within him and automatically poses to him all the problems which a chemical engineer has to face to be successful. His fierce advocacy of the use of this method of training did sometimes bring him into conflict with his colleagues, as he was always afraid that modifications might result in a lowering of his high standards.

It was in keeping with Griffiths's love of his profession and its heritage that his last public appearance was at Mr. Norman Swindin's lecture in Manchester on the life of that grand old man and founder of chemical engineering, George E. Davis. It was then only too apparent to his colleagues that his life was on the ebb tide. In him they have lost a good friend, and the profession has lost a notable servant.

M. B. Donald

\section{NEWS}

Agricultural Physiology at Cambridge:

\section{Dr. John Hammond, F.R.S.}

DR. JoHn Hammond, who on September 30 retires from his post as reader in agricultural physiology in the University of Cambridge and his honorary directorship of the Agricultural Research Council Unit of Animal Reproduction, has brought an immense amount of prestige to British agricultural science. While his contribution to fundamental research is widely appreciated, it will be as the prophet-in the proper sense of the word-of the physiology of reproduction that his name will be honoured. Son of a Norfolk farmer and nephew of a veterinary surgeon, he absorbed as a student the teaching of the late Dr. F. H. A. Marshall on the pure physiology of reproduction. The significance of his life's work is that, at a time when animal production was under the influence of pedigree breeders and the auction mart, on one hand, and the pathological outlook of the veterinary profession on the other, he brought to its development a more positive scientific approach. The essence of his teaching was the extent to which production could be increased by studying the normal physiology of farm animals and not merely by removing the adverse effects of

\section{nd VIEWS}

disease and abnormal physiology. Further, and this may yet be his greatest monument, Dr. Hammond has enthused a large and influential band of disciples, not only within the British Commonwealth but also throughout the world, to initiate research themselves and apply the newer knowledge to the farming industry. Among a wide range of subjects on which he has worked must be mentioned the reproduction and milk production of the cow, which provided the basis of the artificial insemination movement in Britain, and his study of the effect of nutrition and environment on the growth and conformation of sheep and pigs. If the study of animal husbandry ever becomes a profession independent of either agriculture or veterinary science, it will be largely due to the pioneer work and inspiration of John Hammond.

\section{Registrar of Trade Marks in India :
Dr. S. Venkateswaran}

Dr. S. Venkateswaran, deputy registrar of trade marks, India, has been appointed as registrar of trade marks in succession to K. S. Shavaksha, who has recently retired. Dr. Venkateswaran, who is a D.Sc. of the University of Madras and a law graduate of the University of Calcutta, was assistant chemist at 